\title{
CHALLENGES OF CONSUMER PROTECTION REGARDING ARTIFICIAL INTELLIGENCE
}

\author{
Ibolya Stefán \\ PhD student, University of Miskolc, Faculty of Law, Institute of Private Law, Department of Civil Law \\ 3515 Miskolc,Miskolc-Egyetemváros, stefan.ibolya@uni-miskolc.hu
}

\begin{abstract}
Artificial intelligence has gained more significance in the past few years because of the advanced algorithms, increased data storage and computing power. On the contrary, the novelty has several disadvantages, such as lack of transparency or the possibility of data protection problems. Thereby, there is an urgent need to regulate it properly. As a result of the phenomenon, the European Commission has created a Proposal for a Regulation of the European Parliament and of the Council Laying Down Harmonised Rules on Artificial Intelligence and Amending Certain Union Legislative Act' in order to protect EU citizens, consumers. The so-called 'Artificial Intelligence Act' highlights the importance of consumer protection, as it was established in a previous EU document, the White paper on Artificial Intelligence. This paper aims to examine the regulatory framework of AI on the level of the European Union and to describe the challenges of consumer protection in this new digital era.
\end{abstract}

Keywords: artificial intelligence, consumers, consumer protection, challenges, solutions

\section{Introduction}

The appearance and application of artificial intelligence (hereinafter, AI) as the result of digitalisation, the product of the Fourth Industrial Revolution poses an unprecedented challenge for humanity as technology fundamentally changes our current knowledge. The novelty is often compared to the emergence of electricity and steam engines, which have also brought radical changes in recent centuries.

AI is applicable in several areas, such as education (Pedró et al., 2019), healthcare (FoschVillaronga et al., 2020), labour law (Mélypataki, 2019) or public administration (Czékmann et al., 2020; Czékmann et al., 2021). Moreover, it may also help developing countries (Bhattacharya, 2018), or solve the problems of global warming (Gailhofer et al. 2021) and increase productivity, competitiveness. However, in general, consumers use it for private purposes e.g., intelligent/virtual assistance or spam filtering. Consequently, the novelty slowly but surely has become a significant element of our everyday lives; therefore, we may also call this new era the 'Age of AI'. The technology has several benefits for consumers such as innovative and cheaper services and products or the possibility of greater personalisation. On the other hand, the novelty also has many challenges both on the side of government (e.g., consumer protection) and consumers, in this study we focus on the latter.

In this paper, we describe AI and the most significant documents of the technology regarding consumer protection. We also highlight the main challenges of the novelty and try to find some solutions to solve the possible problems. 


\section{Regulatory framework and conceptual basics of Artificial Intelligence}

The European Union has recognized the potentials of AI very early on, therefore it has issued several documents, studies, recommendations, and guidelines in recent years. To examine the technology thoroughly the European Commission established the Independent High-Level Expert on AI (hereinafter, AI HLEG) in 2018.

In April 2019, the European Commission announced a document on 'Building Trust in HumanCentric Artificial Intelligence', which sets out the guidelines of the High-Level Expert Group on Artificial Intelligence. In April, two cardinal documents were published by the Independent HighLevel Expert Group. The 'Ethics Guidelines for Trustworthy AI' details the basics of trust in AI and outlines both the technical and ethical requirements on how to achieve it. The study also provides guidelines for developing national AI strategies. On the other hand, the document, called 'A definition of AI: main capabilities and disciplines' describes the novelty and defines it, as follows: "Artificial intelligence (AI) systems are software (and possibly also hardware) systems designed by humans that, given a complex goal, act in the physical or digital dimension by perceiving their environment through data acquisition, interpreting the collected structured or unstructured data, reasoning on the knowledge, or processing the information, derived from this data and deciding the best action(s) to take to achieve the given goal. AI systems can either use symbolic rules or learn a numeric model, and they can also adapt their behaviour by analysing how the environment is affected by their previous actions." (AI HLEG, 2019)

Considering consumers, another significant document is the so-called 'White paper On Artificial Intelligence - A European approach to excellence and trust'. However, it does not contain specific rules concerning our topic, it highlights the importance of trust regarding the technology, and it states, "Consumers expect the same level of safety and respect of their rights whether or not a product or a system relies on AI." (European Commission, 2020)

It is noteworthy to mention the 'Artificial Intelligence Act' which is a proposal for AI regulation. The proposal follows the risk-based approach; therefore, it differentiates unacceptable (e.g., "contravening the Union values"); high-risk (e.g., used for biometric identification; education or law enforcement); limited-risk (e.g., chatbots) and minimal-risk (e.g., AI-enabled spam filter) AI systems. The document highlights the importance of consumer protection and consumer rights, according to BEUC, The European Consumer Organisation "artificial intelligence law is weak on consumer protection". Monique Goyens, BEUC Director General, commented: "Artificial intelligence technology already appears in the form of virtual assistants, self-driving car features and customer service chat bots. AI can benefit people's daily lives but it also comes with risks. Today's proposal misses the mark when it comes to protecting consumers. It is paramount this proposal gets improved, so consumer protection stays apace with technological advances... People should be able to trust any product or service powered by artificial intelligence, be it 'high-risk', 'medium-risk' or 'low-risk'. The EU must do more to ensure consumers have enforceable rights, as well as access to redress and remedies in case something goes wrong." (BEUC, The European Consumer Organisation, 2021) Besides the risk-based approach the Proposal is cardinal, as it gives an updated definition on AI: „, artificial intelligence system (AI system) means software that is developed with one or more of the techniques and approaches listed in Annex I and can, for a given set of human-defined objectives, generate outputs such as content, predictions, recommendations, or decisions influencing the environments they interact with." (European Commission, 2021) 
Though there are no specific consumer protection rules, we need to mention two important studies which thoroughly examine the issues of consumer protection considering the application of AI. 'Challenges to Consumer Policy in the Digital Age' published by OECD studies the challenges for consumers and governments but also provides solutions for consumer protection. 'New aspects and challenges in consumer protection' also address the main challenges, moreover, it examines data protection, targeted advertising, and liability issues.

\section{Challenges for consumers in a new era}

Challenges of the use of AI appear in several areas - e.g., education, healthcare etc. - however we focus on the viewpoint of consumers, as we consider them more vulnerable because of the informational asymmetry - they have less information, knowledge on AI and the way it works. Therefore, in this chapter we examine the challenges and concerns of the novelty listed by the OECD and the EU, which are the following:

\subsection{Transparency}

Achieving transparency is essential in order to build consumer trust in AI, however, it is not easy, as the technology is quite unknown and very complex. The result of these characteristics is the so-called black box effect (lack of transparency), which occurs when the reasoning behind a decision of AI is not clear. (AI HLEG, 2019). As the 'engine of AI' is data, the technology collects, processes and stores a large amount of it. Although AI and its forms (e.g., smart devices, virtual assistants) often warn consumers about data collecting, processing etc., many consumers are not really aware of what it means technically, that the devices can collect a huge amount of data (e. g., biometric) or intimate information, which can be highly sensitive. According to the OECD study 'Challenges to Consumer Policy in the Digital Age' IoT devices collect various types of data. „In relation to IoT devices, for example, such data could include:

- what a consumer says and does, where she is, who she is with, and what her children are saying and doing

- details about her home, including how much energy is being used, which devices she is using, the contents of her fridge and what television she watches

- physiological signs including sleeping patterns, vital signs, and even sexual activity." (OECD, 2019)

This phenomenon can easily result in data protection breaches. The issues of transparency and data protection lead us to other challenges, namely privacy and security.

\subsection{Privacy and security}

As we mentioned above, smart or IoT devices and AI use large amounts of data (personal or highly sensitive data), mainly to personalise the provided services (consumer profiles), so it can invade the privacy of people. Unfortunately, the failure of the technology or the improper setting can result in data or privacy leakage. (Pal et al., 2020) Therefore, the technology raises data protection and privacy concerns, even though the General Data Protection Regulation regulates data processing strictly.

\subsection{Interoperability}

"Interoperability is key to ensuring that different systems and devices can work together. While some 
restrictions on interoperability may spur innovation and could safeguard privacy and security, some level of interoperability is necessary in order to avoid "lock-in" and support consumer choice and competition. Alongside hardware and software interoperability, consumer data interoperability is likely to be important to facilitating consumer choice and competition. " (OECD, 2019)

\subsection{Accountability and liability}

Considering AI and IoT or smart devices accountability and liability raises questions as the operation of the novelties are quite unknown for the consumers, therefore it is more difficult for them to ascertain the problem. "New product ecosystems and business models can raise questions as to who is ultimately accountable and liable if something goes wrong in a consumer transaction. and to determine who is liable or accountable if the technology is wrong." (OECD, 2019)

\subsection{Discrimination}

As the technology collects a huge amount of data, it can make consumer profiles to personalize the provided services. Personalisation can be beneficial for many consumers, but it can also result in an unfair commercial practice for others. "In particular, if AI learns using data that is inherently biased, these biases will likely carry through to the way in which the AI operates and makes decisions. In addition, to the extent that consumers increasingly rely on AI to make consumer decisions on their behalf, this raises fundamental questions around consumer autonomy and choice that policymakers and stakeholders will need to address." (OECD, 2019) Considering discrimination, we need to mention price discrimination, which means that the algorithm calculates the prices of the same products differently for each consumer. It is based on the consumers' ability or willingness to pay. However, it is known in several sectors e.g., insurance or credit. (Sartor, 2019) The question is, is it right to use the method in general, is it really fair or necessary? Besides price discrimination, ad delivery discrimination is also known "Advertisements that give their addressees an advantage by making them aware of good opportunities may be discriminatory against those who are excluded from such communications." (Sartor, 2019)

\subsection{Targeted advertisement and nudging}

AI systems and algorithms are capable of collecting and monitoring information about the preferences of consumers and establish consumer profiles. In case of profiled users, it is more likely that they may receive targeted adverts, which is suitable for their preferences and encourages them to buy the advertised product or receive news that keeps them on the platform. (Sartor, 2019) The issue of targeted advertising and nudging is that they can manipulate consumers to achieve the advertisers' goals and for profit, which makes them vulnerable (e.g., addictive fashion ads to a compulsive shopper). However, it does not mean that the advert is 'intentionally malicious', the aim of the algorithm is to fulfil the programmed task.

Nudging is related to targeted advertisement, as „Nudges meant to induce desired behaviour patterns can be exercised in subtle ways, by framing the contexts in which individuals are going to exercise their choices and selecting what information is made available to each of them." (Sartor, 2019) Pusztahelyi in her paper examined emotional AI and nudging, according to her "The emotional AI capable to recognise and imitate human emotions, well equipped with the up-to-date results of behavioural sciences, has an effective influence upon the rather irrational human decision-making, especially with means of profiling and personalizing and it could even target the most vulnerable 
consumers exposed emotionally in a particular case." (Pusztahelyi, 2020) Therefore, it can affect the decisions of consumers. (Pusztahelyi, 2021) As a result, we can state that both targeted advertisement and nudging can result in unfair commercial practices, which must be strictly regulated in order to protect consumers.

\section{Summary}

In this study, we described the regulatory framework of AI relating to consumer protection, although there are no specific rules for the topic. As a result, we focused only on the most important documents of AI that can be considered milestones (because the papers defined AI, set out important guidelines for the Member States or established the risk-based approach) and addressed the main challenges of consumer protection.

The technology and its manifestation (virtual assistants, IoT devices) raise many concerns and issues regarding consumers. AI smart or IoT devices collect and process a large amount of personal, often highly sensitive data. Consequently, the novelties are invading our privacy. Therefore, it is extremely important to answer the question, how can we protect consumers in the modern, interconnected era, where many devices and services are based on AI to achieve personalisation and better user experience?

We believe that the mentioned challenges, issues can be solved by ensuring the transparency of AI (e.g., transparent operation of AI, warn consumers when AI-based product or service used, guarantee the explanation of the technology and its operation) and educating consumers in general about the operation of artificial intelligence and devices that uses the technology. As a result, the consumers may find one's way in this modern, digital environment. Furthermore, they can make decisions about their data, privacy and life.

On the other hand, strict rules should be established to protect vulnerable consumers against the technology and provide them technology-specific rights, such as the right to explanation, right to have a human answer (in addition, in sensitive cases AI should not make decisions) or right to be protected from abusive manipulation.

\section{Acknowledgements}

This research was "Supported by the ÚNKP-20-3 New National Excellence Program of the Ministry for Innovation and Technology from the source of the National Research, Development and Innovation Fund."

\section{References}

[1] BEUC, The European Consumer Organisation (2021). EU proposal for artificial intelligence law is weak on consumer protection. (Press release, 21. 04. 2021.) https://www.beuc.eu/publications/eu-proposal-artificial-intelligence-law-weak-consumerprotection/html (Date of download: 20 $0^{\text {th }}$ July 2021)

[2] Bhattacharya, K. (2018). How AI could transform developing countries. Oxford Government Review, Number 3, 2018 October, 24-25. 
[3] Czékmann, Zs.. Kovács, L., Ritó E. (2020). A mesterséges intelligencia alkalmazásának lehetőségei az állimgazgatásban. Infokommunikáció és jog 2020/2. https://infojog.hu/kovacslaszlo-czekmann-zsolt-rito-evelin-a-mesterseges-intelligencia-alkalmazasanak-lehetosegei-azallamigazgatasban-2020-2-75-e-kulonszam/ (Date of download: $9^{\text {th }}$ of July)

[4] Czékmann, Zs., Kovács, L., Ritó E. (2021). Mesterséges intelligencia az államigazgatásban. In: Török, B.; Ződi Zs. (Eds.), A mesterséges intelligencia szabályozási kihívásai: Tanulmányok a mesterséges intelligencia és a jog határterületeiről (pp. 387-402.)., Ludovika Egyetemi Kiadó.

[5] European Commission (2019). Building trust in human-centric artificial intelligence. $\operatorname{COM(2019)} 168$ final. Brussels, 8.4.2019.

[6] European Commission (2020). White paper on artificial intelligence - A European approach to excellence and trust. $\mathrm{COM}(2020) 65$ final. Brussels, 19.2.2020.

[7] European Commission (2021). Proposal for a regulation of the European Parliament and of the Council laying down harmonised rules on artificial intelligence (Artificial Intelligence Act) and amending certain union legislative acts. $\mathrm{COM(2021)} 206$ final. Brussels, 21.4.2021.

[8] Fosch-Villaronga, E., Chokoshvili, E., Binz Vallevik, V., Ienca, M., Pierce, R. (2020). Implementing AI in healthcare: An ethical and legal analysis based on case studies. In: Hallinan, D.; Leenes, R. \& De Hert, P. (Eds.), Data protection and privacy: Data protection and artificial intelligence ( $1^{\text {st }}$ ed., pp. 1-37.)., Hart Publishing. https://doi.org/10.5040/9781509941780.ch-007

[9] Gailhofer, P., Herold, A., Schemmel, J. P., Scherf, C., Urrutia, C., Köhler, A. R., Braungardt, S. (2021). The role of artificial intelligence in the European Green Deal, Study for the special committee on Artificial Intelligence in a Digital Age (AIDA), Policy Department for Economic, Scientific and Quality of Life Policies, European Parliament, Luxembourg.

[10] Independent High-Level Expert Group (2019). A definition of AI: main capabilities and discipline. Brussels, 8 April 2019.

[11] Independent High-Level Expert Group (2019). Ethics guidelines for trustworthy AI. Brussels, 8 April 2019.

[12] Independent High-Level Expert Group on Artificial Intelligence (2019). A definition of AI: Main capabilities and disciplines. pp. 1-7. (Date of download: $9^{\text {th }}$ July 2021)

[13] Mélypataki, G. (2019). Effects of artificial intelligence on labour law and labour market: Can AI be a boss? European Integration Studies, 2019/1. (2020), 64-74.

[14] OECD (2019). Challenges to consumer policy in the digital age.

[15] Pal, S., Hitchens, M., Rabehaja, T., Mukhopadhyay, S. (2020). Security requirements for the internet of things: A systematic approach. Sensors, 20/2020., 5897-5932. https://doi.org/10.3390/s20205897

[16] Pedró, F., Subosa, M., Rivas, A., Valverde, P. (2019). Artificial intelligence in education: Challenges and opportunities for sustainable development. Working papers on education policy. United Nations Educational, Scientific and Cultural Organization, 7, place de Fontenoy, 75352 Paris 07 SP, France.

[17] Pusztahelyi, R. (2020). Emotional AI and its challenges in the viewpoint of online marketing. Curentul Juridic 23(2), 13-31.

[18] Pusztahelyi, R. (2021). Az "érzelmes MI" felhasználása az online marketing világában. In: Török, B.; Ződi Zs. (Eds.), A mesterséges intelligencia szabályozási kihívásai: Tanulmányok a mesterséges intelligencia és a jog határterületeiröl (pp. 439-464.)., Ludovika Egyetemi Kiadó. 
[19] Sartor, G. (2019). Artificial Intelligence: Challenges for EU citizens and consumers. Policy Department for Economic, Scientific and Quality of Life Policies Directorate-General for Internal Policies.

https://www.europarl.europa.eu/RegData/etudes/BRIE/2019/631043/IPOL_BRI(2019)631043_ EN.pdf (Date of download: $28^{\text {th }}$ of August, 2021.)

[20] Sartor, G. (2020). New aspects and challenges in consumer protection. Study for the committee on the Internal Market and Consumer Protection, Policy Department for Economic, Scientific and Quality of Life Policies, European Parliament, Luxembourg. 